DOI:

УДК 347.453.1

\title{
Юлія Труфанова,
}

кандидат юридичних наук, доиент кафедри циивільного права і процесу

Тернопільського національного економічного університету ORCID: https://orcid.org/0000-0003-4310-3061

\section{Михайло Баженов,} дочент кафедри циивільного права та правового забезпечення туризму Київського університету туризму, економіки і права

\section{ПРАВОВІ ПІДСТАВИ РОЗІРВАННЯ ДОГОВОРУ НАЙМУ (ОРЕНДИ) НА ВИМОГУ НАЙМАЧА}

Розглянуто підстави розірвання договору найму на вимогу наймача. Розкрито механізм застосування підстав розірвання договору на вимогу наймача та проаналізована відповідна судова практика.

Ключові слова: договір найму, наймодавець, наймач, оренда, підстави розірвання договору.

Труфанова Ю.

Правовые основания расторжения договора найма (аренды) по требованию нанимателя

В статье рассматриваются основания расторжения договора найма по требованию нанимателя. Раскрыт механизм применения оснований расторжения договора по требованию нанимателя и проанализирована соответствующая судебная практика.

Ключевые слова: договор найма, наймодатель, наниматель, аренда, основания расторжения договора.

Trufanova Yu.

Legal grounds for termination of lease agreement on the renter request.

The article deals with the grounds for termination of the employment contract at the request of the employer. The author discloses the mechanism of application of grounds for termination of the contract at the request of the employer and the relevant jurisprudence is analyzed.

The relevance of the article is due to the fact that the domestic jurisprudence reveals the inaccuracy of certain legislative provisions of civil and commercial legislation of Ukraine regarding the institute of termination (termination) of the lease (lease). Therefore, there is a need for a new scientific and theoretical understanding of their content in order to properly regulate the employment relationship and the effectiveness of law enforcement activities in this area.

In the overwhelming majority, the subject of research of scholars are only specific issues of termination of the contract of employment in the context of doctrinal analysis of the legal regulation of certain types of employment relations (leases). An important component of the mechanism of application of grounds for termination of the contract at the request of the employer is the need to address certain practical problems of such application.

The article aims to to analyze the legal grounds for termination of the lease (lease) on the initiative of the tenant and to take a systematic approach to determining the reasons for such termination of the lease in modern civil law and and modern judicial practice.

Systematic analysis of the provisions of Chapter 58 of the Civil Code of Ukraine allowed the author to conclude that the grounds for termination of the contract of employment at the request of the employer, except Art. 784, also defined in paragraph 4 of Part 2 of Art. 768, Part 2 of Art. 769 and paragraph 2 of Part 3 of Art. 776 of the Central Committee of Ukraine. The termination of the contract in the last three cases is one of the alternative legal consequences stipulated by these norms and is applied by the employer when he is not interested in the further existence of a legal relationship between him and the landlord. Similar situations with the landlord, the list of grounds for termination of the lease agreement at the request of the tenant is open.

Keywords: lease agreement, lessor's, renter, lease, grounds for termination of agreement.

Актуальність статті та постановка проблеми. Вітчизняна судова практика виявляє нечіткості окремих законодавчих положень цивільного та господарського законодавства України щодо інституту при-

() Юлія Труфранова, Михайло Баженов, 2019 
Цивільне право і цивільний процес. Сімейне право. Трудове право. Міжнародне приватне право. Господарське право. Господарсько-процесуальне право.

пинення (розірвання) договору найму (оренди), що обумовлює потребу науково-теоретичного осмислення їхнього змісту з метою належного правового регулювання відносин найму та ефективності правозастосовної діяльності у цій сфері.

Переважно предметом дослідження науковців виступають лише окремі питання розірвання договору найму в контексті доктринального аналізу правового регулювання окремих видів відносин найму (оренди). Важливою складовою механізму застосування підстав розірвання договору на вимогу наймача $є$ необхідність вирішення окремих практичних проблем такого застосування.

Аналіз останніх досліджень і публікацій. Окремі дослідження з цієї проблематики здійснювали вітчизняні і зарубіжні вчені, зокрема М. І. Брагінський, Н. М. Бойко, А. Г. Брунь, І. Р. Калаур, А. В. Коструба, Н. С. Кузнєцова, В. В. Луць, Р. А. Майданник, І. В. Спасибо-Фатєєва та ін.

Мета статті - проаналізувати правові підстави розірвання договору найму (оренди) з ініціативи наймача та здійснити системний підхід до визначення підстав такого припинення договору найму в сучасному цивільному законодавстві та сучасній судовій практиці.

Виклад основного матеріалу дослідження. Підстави розірвання договору оренди (найму) з ініціативи наймача виокремлені у ст. 784 Цивільного кодексу України (далі - ЦК України).

Згідно з ч. 2 ст. 776 ЦК України наймодавець зобов’язаний здійснити капітальний ремонт речі, якщо інше не предбачено договром. Саме з неналежним виконанням цих двох обов'язків пов'язані підстави розірвання договору за вимогою наймача:

1) наймодавець передав у користування річ, якість якої не відповідає умовам договору та призначенню речі;

2) наймодавець не виконує свого обов'язку щодо проведення капітального ремонту речі.

Щодо першої niдстави розірвання договору найму (оренди) доречно зауважити, що для застосування положення ч. 1 ст. 784 ЦК України необхідно, щоб наймачеві була фактично передана річ, яка не відповідає умовам договору та призначенню речі. Якщо наймодавець не передав річ, то наймач може відмовитися від договору найму та вимагати відшкодування збитків на підставі п. 2 ч. 1 ст. 766 ЦК України.

Звертаємо увагу, що в законодавстві України існує певна неузгодженість між нормами п. 1 ч. 1 ст. 784 ЦК України та ч. 3 ст. 767 ЦК України. Відповідно до останньої наймач, приймаючи річ від наймодавця, зобов'язаний перевірити ії справність. Якщо він у момент передання речі у користування не переконається у їі справності, річ вважається такою, що передана в належному стані. Через те, вимагаючи розірвання договору, наймач повинен довести прихований характер «невідповідності» речі умовам договору, введення його в оману чи інші поважні причини неможливості виявлення «невідповідності» речі умовам договору у момент передання. Таким чином, обов'язок наймача - довести про неналежний стан переданої речі. Таку саму позицію підтримує і ВГС України. Так, у постанові від 22 вересня 2009 р. у справі № 24/13пд суд касаційної інстанції вказав, що наймач, приймаючи річ, зобов'язаний відповідно до ч. 3 ст. 767 ЦК України перевірити іiі якість, а тому суди неправомірно переклали обов'язок доведення належної якості речі на наймодавця. ВГС України також вказав на обмеження випадків застосування п. 2 ч. 1 ст. 784 ЦК України - «висновки судів щодо природи правовідносин, в яких можливе застосування статті 784 ЦК України (в будь-якому разі, навіть коли орендарю на момент передачі речі було відомо про їі неналежний стан) суперечать визначеним у законодавстві підставам застосування ст. 784 ЦК України, як негативного наслідку для орендодавця у разі його неправомірної поведінки, порушення ним відповідних зобов'язань» [1].

Вважаємо, що така правова позиція відповідає вимогам розумності, добросовісності та справедливості, оскільки наймодавець не може передати наймачеві всупереч його волі річ, якість якої не відповідає умовам договору та їі призначенню. Через це наймач повинен перевірити якість і комплектність речі, переданої в найм. Знайшовши невідповідність між якістю речі, яка передана у найм і умовами договору, наймач може іiі не приймати для користування. Якщо ж наймач свідомо прийняв річ, якість якої не відповідає умовам договору, то відсутні підстави для розірвання договору на основі п. 1 ч. 1 ст. 784 ЦК України.

Розірвання договору з розглядуваної підстави ускладнюється тим, що, крім доказів невідповідності якості речі умовам договору, потрібно також довести, що за ці недоліки відповідає наймодавець, оскільки до передання наймач не користувався річчю і не мав змоги своїми діями зумовити такий іiї стан, який би не відповідав умовам договору. 3 моменту передання речі встановити винуватця наявних на момент розгляду справи недоліків речі стає значно важче. Судова практика сформувала твердження, згідно 3 яким «наймодавець не відповідає за недоліки майна, які не були ним спричинені» [2]. 
Труфанова Ю., Баженов М.

Правові підстави розірвання договору найму (оренди) на вимогу наймача

Доцільно зазначити, що розірвання договору з розглядуваної підстави зазвичай не повинно значно віддалятися у часі від моменту передання речі, оскільки, якщо наймач не може користуватися річчю, бо ії якість не відповідає умовам договору, то він повинен вжити заходів для відновлення своїх порушених прав та інтересів. Якщо річ використовується наймачем, то підстав для розірвання договору немає. Виняток становлять ті випадки, коли річ містить приховані недоліки, які виявилися у процесі ії використання. Для доведення неможливості завчасного виявлення невідповідності речі умовам договору може призначатися відповідна експертиза.

Якщо ж наймодавець передав річ з гарантією їі якості протягом всього строку найму (ч. 1 ст. 768 ЦК України), то у випадку погіршення властивостей речі, за які не відповідає наймач, та які перешкоджають їі використанню відповідно до умов договору, наймач має право вимагати розірвання договору та відшкодування завданих збитків (п. 4 ч. 2 ст. 768 ЦК України).

Оскільки наявність недоліків у речі пов'язана з недобросовісністю наймодавця, то існує позиція, згідно з якою більш доцільно подавати позов не про розірвання договору на підставі п. 1 ч. 1 ст. 784 ЦК України, а позов про визнання договору недійсним на підставі ч. 1 ст. 230 ЦК України - у зв’язку з обманом зі сторони наймодавця. Вигода наймача в разі задоволення позову полягає у подвійному відшкодуванні збитків та моральної шкоди стороною, винною в обмані контрагента (ч. 2 ст. 230 ЦК України). Відповідно до ч. 1 ст. 230 ЦК України обман наявний, якщо сторона заперечує наявність обставин, які можуть перешкодити вчиненню правочину, або якщо вона замовчує їх існування. Слід зазначити, що довести у діях наймодавця наявність обману, який завжди здійснюється лише з прямим умислом, значно важче, ніж факт невідповідності переданої речі умовам договору з причин, за які відповідає наймодавець.

Неоднозначною є позиція судів щодо співвідношення норм ст. 230 ЦК України та п. 1 ч. 1 ст. 784 ЦК України. Так, ВГС України у постанові від 04.04.2012 року у справі № 30/5009/7347/11, переглядаючи ii матеріали про визнання недійсним договору найму у зв'язку з обманом зі сторони наймодавця щодо якості переданої речі відзначив, що відповідно до п. 1 ч. 1 ст. 784 ЦК України наявність недоліків майна, які перешкоджають його використанню за призначенням є підставою для розірвання договору з ініціативи наймача, а не визнання його недійсним [3].

Якщо якість переданої речі не відповідає умовам договору через необхідність проведення ремонту, то важливе значення має вид ремонту, який потрібно провести (капітальний чи поточний), а також встановлення договірної сторони, яка зобов'язана його здійснити. Оскільки відмежування капітального та поточного ремонтів може потребувати спеціальних знань, то для вирішення справи про розірвання договору за таких умов може призначатися судова експертиза.

Друга підстава для розірвання договору найму (оренди) з ініціативи наймача передбачена п. 2 ч. 1 ст. 784 ЦК України, відповідно до якої наймач має право вимагати розірвання договору найму, якщо наймодавець не виконує свого обов'язку щодо проведення капітального ремонту речі. Наймодавець зобов'язаний проводити капітальний ремонт, якщо інше не передбачено самим договором.

Автори науково-практичного коментаря під редакцією I. В. Спасибо-Фатєєвої вважають, що, на відміну від аналогічного права наймодавця (п. 4 ч. 1 ст. 783 ЦК України), наймач може вимагати розірвання договору, якщо наймодавець взагалі не виконує свого обов'язку, в той час як наймодавець може заявити таку вимогу у тому разі, коли наймач не розпочав до виконання капітального ремонту [4, с. 452]. Між цими юридичними фактами існує відмінність. Так, якщо протягом судового процесу наймодавець (наймач) приступить до проведення капітального ремонту, то з огляду на положення п. 2 ч. 1 ст. 784 ЦК України (п. 4 ч. 1 ст. 783 ЦК України), суд не матиме підстав для задоволення позову.

Формулювання п. 2 ч. 3 ст. 776 ЦК України, вказує на вже допущене і не обов'язково тривале на момент винесення рішення судом порушення, як на підставу для розірвання договору. Час початку здійснення капітального ремонту визначається або умовами договору, або нагальною необхідністю, викликаною неможливістю подальшого використання речі за призначенням без проведення капітального ремонту. Відтермінування цього обов'язку завдає шкоду інтересам наймача і може переважити вигоди від подальшого його використання, тому формулювання підстави розірвання договору у п. 2 ч. 3 ст. 776 ЦК України більшою мірою сприятиме захисту інтересів наймача порівняно з п. 2 ч. 1 ст. 784 ЦК України.

Крім права вимагати розірвання договору і відшкодування збитків, наймач відповідно до п. 1 ч. 3 ст. 776 ЦК України може відремонтувати річ, зарахувавши вартість ремонту в рахунок плати за користування річчю, або вимагати відшкодування вартості ремонту. Також наймач має право, за згодою 3 наймодавцем, здійснити поліпшення речі. Відмінність між цими поняттями полягає у тому, що ремонт (поточний і капітальний) має відновити властивості (стан) речі і забезпечити ії використання за призначенням у меж- 
Цивільне право і цивільний процес. Сімейне право. Трудове право. Міжнародне приватне право. Господарське право. Господарсько-процесуальне право.

ах попередніх показників, а в результаті поліпшення покращуються характеристики речі, що зумовлює збільшення майбутньої вигоди, отриманої від використання такої речі, або створюється нова річ. Вимоги до форми погодження на здійснення поліпшень речі можна встановлювати у договорі або законодавстві. Наприклад, поліпшення державного майна здійснюється за погодженням з Фондом державного майна у формі подання заяви, а сама процедура отримання погодження врегульована наказом Фонду державного майна України від 25.05.2018 року № 686.

Чинне законодавство не регламентує критерії вибору між відшкодуванням витрат на здійснення поліпшень та зарахуванням їх вартості в рахунок плати за користування річчю. Вважаємо, що такий вибір наймач здійснює на власний розсуд і не потребує погодження з наймодавцем. Оскільки наймач має право на відшкодування витрат на поліпшення речі, то існує позиція, згідно з якою вимога щодо зарахування іiі вартості в рахунок плати за користування річчю підпадатиме під залік зустрічних вимог у порядку ст. 601 ЦК України [4, с. 432]. Однак предметом заліку відповідно до ст. 601 ЦК України є зустрічні однорідні вимоги, строк виконання яких настав, а також вимоги, строк виконання яких не встановлений або визначений моментом пред'явлення вимоги. Спільним у перерахованих вимогах є те, що на момент заліку існує заборгованість за певними зобов'язаннями.

Таким чином, вимога щодо зарахування вартості невідокремлюваних поліпшень у рахунок плати за користування річчю могла б зараховуватися за наявної на момент заліку заборгованістю 3 внесення плати за користування річчю. Проте норма ч. 3 ст. 778 ЦК України дає змогу застосовувати цю вимогу і щодо плати за користування річчю, яка справлятиметься з наймача за майбутнє користування нею. Отже, норма ч. 3 ст. 778 ЦК України встановлює спеціальну правову конструкцію, на яку не поширюється дія ст. 601603 ЦК України. Права, передбачені ч. 3 ст. 778 ЦК України, не виникають у наймача у разі здійснення поліпшення речі без згоди наймодавця. Якщо поліпшення можна відокремити від речі без погіршення ііi стану, то наймач має право залишити ці поліпшення собі.

Особливий інтерес становлять випадки поліпшення майна, в результаті яких утворюється нова річ. У такому разі наймач стає співвласником новоствореної речі. Водночас відповідно до ч. 4 ст. 778 ЦК України частка наймача у праві власності відповідає вартості його витрат на поліпшення речі, якшо інше не встановлено договором або законом. На практиці в процесі укладання договорів найму не завжди його сторони погоджують умови, якими у таких випадках регулюють відносини спільної власності між ними, що вказує на актуальність дослідження умов виникнення у наймача права часткової власності на новоутворену річ. 3 конструкції ч. 4 ст. 778 ЦК України можна виокремити такі умови для виникнення цього права: 1) поліпшення повинні стосуватися саме переданої в найм речі; 2) поліпшення повинні бути здійснені за згодою наймодавця; 3) у результаті поліпшення має бути створена нова річ; 4) витрати на поліпшення поніс наймач. Недотримання будь-якої із зазначених чотирьох умов вилучає виникнення спільної часткової власності.

Складним є питання відмежування створення нової речі у процесі поліпшення речі від суміжних категорій: збільшення їі вартості, підвищення корисних показників тощо. Так, ВГС України у постанові від 07.10.2009 року у справі № 16/183-07 вказав, що сама лише обставина збільшення вартості орендованого майна не може бути достатньою підставою для висновку про створення нової речі. Проведення перепланування і реконструкції внутрішніх приміщень в ході капітального ремонту в межах капітальної будівлі не створює нову річ, а лише їі поліпшує [5]. У постанові від 27.11.2013 року у справі № 921/307/13-г/4 ВГС України зауважив, що слід відмежовувати поняття «капітальний ремонт», тобто комплекс ремонтно-будівельних робіт, без проведення якого приміщення неможливо використовувати за призначенням, від поняття «поліпшення орендованого майна», яке передбачає не лише здійснення відновлення належного стану об’єкта (як при ремонті), а наявність витрат у зв'язку з модернізацією, модифікацією, дообладнанням цього об'єкта, що зумовлює збільшення майбутніх вигод, які отримуються від використання такого майна. Тобто при ремонті відбувається відновлення стану об'єкта оренди, його корисних властивостей, а при поліпшенні - зміна майна [6]. Відмежувати поліпшення майна від інших суміжних категорій можна лише у результаті судової експертизи, що має велике значення для вирішення справи. У постанові ВГС України від 06.04.2011 року у справі № 15-176-3468 суд касаційної інстанції погодився з висновками судів попередніх інстанцій та висновком судової експертизи про створення у результаті реконструкції якісно нової речі [7].

Очевидним, однозначного висновку щодо можливості чи неможливості створення нової речі у результаті реконструкції у судовій практиці немає. Як зазначає М. О. Легенченко, питання встановлення факту створення нової речі належить до компетенції суду і не може виноситися на вирішення експерту [8, c. 129]. Автор також вказує, що створення нової речі згідно зі ст. 332 ЦК України можливе лише в результа- 
Труфанова Ю., Баженов М.

Правові підстави розірвання договору найму (оренди) на вимогу наймача

ті переробки попередньої речі шляхом її використання як матеріалу, а тому не може привести до створення нової речі капітальний ремонт, внутрішнє перепланування, переобладнання приміщення, у тому числі надання об'єктові нового функціонального призначення в межах наявної капітальної будівлі.

Крім отримання згоди наймодавця на проведення поліпшення, в результаті якого створюється нова річ, для виникнення права спільної власності на новостворену річ потрібно, щоб будівельні роботи були погоджені з органами архітектурно-будівельного контролю. В іншому разі це буде визнано самовільним будівництвом.

Оскільки поняття «ремонт» та «поліпшення», в результаті яких була створена нова річ не є взаємозамінними, то розраховуючи частку наймача в результаті створення нової речі (під час поліпшення предмета найму) треба враховувати вартість саме тих здійснених поліпшень, які привели до створення нової речі, без врахування вартості здійснених ремонтних робіт і поліпшень, які не привели до створення нової речі. Відмежування цих витрат також належить здійснити під час судової експертизи.

Висновки. Системний аналіз положень Глави 58 ЦК України дає змогу нам зробити висновок, що підстави розірвання договору найму на вимогу наймача, окрім ст. 784, визначені також у п. 4 ч. 2 ст. 768, ч. 2 ст. 769 та п. 2 ч. 3 ст. 776 ЦК України. Розірвання договору у трьох останніх випадках є одним із альтернативних правових наслідків, які передбачені цими нормами, і застосовується наймачем тоді, коли він не зацікавлений у подальшому існуванні правового зв’язку між ним і наймодавцем. Подібні ситуації 3 наймодавцем, перелік підстав розірвання договору найму на вимогу наймача є відкритим.

\section{Список використаних джерел}

1. Постанова Вищого господарського суду України від 22.09.2009 р. у справі №24/13пд. Сдиний державний реєстр судових рішень. URL : http://reyestr.court.gov.ua/Review/4887536 (дата звернення: 25.06.19).

2. Постанова Вищого господарського суду України від 17.12.2007 р. у справі № 36/205. Сдиний державний реєстр судових рішень. URL : http://www.reyestr.court.gov.ua /Review/1237677 (дата звернення: 25.06.19).

3. Постанова Вищого господарського суду України від 04.04.2012 р. у справі №30/5009/7347/11. Єдиний державний реєстр судових рішень. URL: http://ww.reyestr.court.gov.ua/Review/22472078 (дата звернення: 25.06.19).

4. Цивільний кодекс України: наук.-практ. коментар (пояснення, тлумачення, рекомендації з використанням позицій вищих судових інстанцій Міністерства юстиції, науковців, фахівців) / за ред. І. В. Спасибо-Фатєєвої. Харків: ФО-П Лисяк Л. С., 2013. Т. 8: Договори про передачу майна у власність та користування. Серія : Коментарі та аналітика. 670 с..

5. Постанова Вищого господарського суду України від 07.10.2009 р. у справі № 16/183-07. Сдиний державний реєстр судових рішень. URL : http://www.reyestr.court.gov.ua/Review/5068629 (дата звернення: 25.06.19).

6. Постанова Вищого господарського суду України від 27.11.2013 р. у справі № 921/307/13-г/4. Єдиний державний реєстр судових рішень. URL : http://www.reyestr.court.gov.ua/Review/35548576 (дата звернення: 25.06.19).

7. Постанова Вищого господарського суду України від 06.04.2011 р. у справі № 15-176-3468. Єдиний державний реєстр судових рішень. URL : http:/www.reyestr.court.gov.ua/Review/14757407 (дата звернення: 25.06.19).

8. Легенченко М. О. Практичні аспекти оренди комунального майна : наук.-практ. посіб. Київ: Істина, 2013. $216 \mathrm{c}$.

\section{References}

1. Postanova Vyshchogo gospodarskogo sudu Ukrainy u spravi № 24/13пд [Resolution of the High Commercial Court of Ukraine in reference number №24/13пд]. (2009, September 22). Judicial decisions of the State court of Ukraine. Retrieved from: http://reyestr.court.gov.ua/Review/4887536 [in Ukrainian].

2. Postanova Vyshchogo gospodarskogo sudu Ukrainy u spravi № 36/205 [Resolution of the High Commercial Court of Ukraine in reference number №36/205]. (2007, December 17). Judicial decisions of the State court of Ukraine. Retrieved from: http://www.reyestr.court.gov.ua /Review/1237677 [in Ukrainian].

3. Postanova Vyshchogo gospodarskogo sudu Ukrainy u spravi №30/5009/7347/11 [Resolution of the High Commercial Court of Ukraine in reference number № 30/5009/7347/11]. (2012, April 04). Judicial decisions of the State court of Ukraine. Retrieved from: http://www.reyestr.court.gov.ua/Review/22472078 [in Ukrainian]. 
Цивільне право і цивільний процес. Сімейне право. Трудове право. Міжнародне приватне право. Господарське право. Господарсько-процесуальне право.

4. Spasibo-Fatieva, I. V. (2013). Tsyvilnyi kodeks Ukrainy: nauk.-prakt. komentar (poyasnennia, tlumachenia, rekomendatsii z vykorystaniam pozytsii vyshukh sudovykh instantsii Ministerstva yustytsii, naukovtsiv, fakhivtsiv) [Civil Code of Ukraine: Sciences. Pract. comment (explanation, interpretation, recommendations using the positions of higher courts of the Ministry of Justice, scientists, specialists) ]. Dogovory pro peredachu maina u vlasnist ta korystuvania. Seria «Komentari ta analityka»-Property and use transfer agreements, vol. 8. Kharkiv: FOP Lysiak [in Ukrainian].

5. Postanova Vyshchogo gospodarskogo sudu Ukrainy u spravi № 16/183-07 [Resolution of the High Commercial Court of Ukraine in reference number №16/183-07]. (2009, October 07). Judicial decisions of the State court of Ukraine. Retrieved from: http://www.reyestr.court.gov.ua/Review/5068629 [in Ukrainian].

6. Postanova Vyshchogo gospodarskogo sudu Ukrainy u spravi № 921/307/13-г/4 [Resolution of the High Commercial Court of Ukraine in reference number №921/307/13-г/4 (2013, November 27). Judicial decisions of the State court of Ukraine. Retrieved from: http://www.reyestr.court.gov.ua/Review/35548576 [in Ukrainian].

7. Postanova Vyshchogo gospodarskogo sudu Ukrainy u spravi № 15-176-3468 [Resolution of the High Commercial Court of Ukraine in reference number №15-176-3468 (2011, April 06). Judicial decisions of the State court of Ukraine. Retrieved from: http:/www.reyestr.court.gov.ua/Review/14757407 [in Ukrainian].

8. Legenchenko, M. O. (2013). Praktychni aspekty orendy komunalnogo maina [Practical aspects of lease of communal property]. Kyiv: Istyna [in Ukrainian].

Стаття надійшла до редакції 06.12.2019. 